\title{
戦時期から戦後における高学歴層の流動性と 戦後階層システムの形成
}

—SSM 調査の再分析から 1940 年代を読み直す

\section{岩井八郎*}

戦時期から戦後にまたがる 1940 年代は, 軍需産業への動員, 兵役, 兵役か らの帰還など日本人男性の経歴が最も流動的であった。この時期の経歴の流動 性と戦後階層システムの形成との関係について, 戦時体制と戦後社会に関する 連続性と非連続性をめぐる議論を整理した上で，本稿は 1955 年，65 年， 75 年 の 3 時点における SSM 調査の職業経歴データを出生コーホート別, 学歴別に 再構成し, 高学歴層に焦点を当てた分析を行っている. 出生コーホート別に従 業先の産業, 従業先移動, 職業的地位の年齢にともなう変化を提示し, さらに 出生コーホート別に本人の職業的地位達成に及ぼす教育と父職業の効果に関す る重回帰分析の結果を示している. 高学歴層（とくに 1910 年代出生）は, 戦 時期に軍需に関係する鉄鋼機械関係の製造業に従事するか兵役に携わるが，戦 時から戦後にかけて従業先移動も高い. 経歴の流動性が高いが, 終戦後に製造 業の就業機会が悪化したにもかかわらず，製造業に就業する割合が高く，良好 な地位を形成していた。本稿は, 高学歴層の流動性が高かった結果, 戦後階層 システムの安定性が形成された点を示し，1940 年代を読み直す.

キーワード : 戦時体制, 経歴の流動性, 高学歴層

\section{1 はじめに}

第二次世界大戦, とりわけ「太平洋戦争」の戦時から敗戦後にまたがる 1940 年 代は, 日本人男性の経歴の流動性が例外的に高まった時期であった. 戦時体制下に おいて, 軍需産業への動員が強制的に進められ, また多くの男性は兵役によって戦 場へと送られた。 そして敗戦直後には, 軍需工場の閉鎖, 軍隊からの復員, 海外か らの引揚など, 大規模な人口移動を短期間に余儀なくされた。戦時下から敗戦後に かけての産業別有業人口の推移をみると，1940 年から 44 年までの間で，製造業の 増加と商業の減少が著しい。製造業の中でも，軍需の中心であった金属機械工業の 人口は約 230 万人増加したのに対して, 紡績業では約 80 万人減少した. しかし敗 戦後, 農林水産人口は 1944 年から 47 年までに約 400 万人増加し, 第三次産業の中

* 京都大学大学院教育学研究科教育社会学講座教授 iwai.hachiro.2r@kyoto-u.ac.jp 
でも商業が 1944 年から 50 年までに約 200 万人増加した，それに対して，製造業人 口は大幅に減少し，金属機械工業人口は約 330 万人も減った（中村 [1993]2012, 上；454）. 1940 年代に生じた強制的な経歴の移動は, 戦前から戦中を経て高度成 長期に至る日本人の人生パターンの変化のなかで, どのように位置付けられるのか. この時期の経歴の流動性は, 戦後の安定的な日本社会の形成とどのように関係する のか.

1920 年代，30 年代の日本社会は，すでに都市化や産業化が進行し，中等教育機 会と高等教育機会の大幅な拡大もあり, 戦後日本社会の「原型」が形成されつつあ った。一方，1950 年代になると「日本的経営」論に代表されるように日本人男性 の経歴の安定性と非流動性が強調された。両時期に挟まれた 1940 年代について, 本稿はその時期の経歴の特徵を SSM 調査の職業経歷を出生コーホート別, 学歴別 に再構成することによって明らかにし，戦後の階層システムとの関係を検討する. とくに本稿では, 1940 年代の高学歴層の経歴に注目する。一般に高学歴層は高い 職業的地位を約束され, 安定的な経歴を歩むと考えられているが, 1940 年代にお ける経歴の流動性は高い. 1920 年代, 30 年代は大学・尃門学校卒業生にとって 「就職難」の時期であった，戦時体制のもとで就職難は解消され，さらに高等教育 機会, とくに官立と私立の専門学校が拡充された. そして 1940 年代には軍需産業 への移動や兵役があり, 終戦とともに軍需産業の閉鎖, 戦争からの帰還がある. 本 稿の分析結果によれば，高学歴層は終戦後に製造業の就業機会が悪化したにもかか わらず，製造業で仕事を得る割合が高く，良好な地位を形成していた，戦前から戦 後にかけて階層システムの安定性が持続した背後に, 高学歴層の経歴の流動性があ る. 本稿はこの流動性の高さの意味を考察したい.

1955 年より 10 年間隔で実施されてきた「社会階層と社会移動（SSM）」調査は, 調査対象者の出身階層, 学歴, 調査時点の職業的地位のみならず, 学校終了後の職 業経歴について年齢に途切れのない形式で回顧的に情報を収集している. 2005 年 までの SSM 調査対象者は, 調査時点における 20 歳から 69 歳であった。したがっ て, 現在利用可能なデー夕には, 1955 年調查の 1886 年出生から 2005 年調查の 1985 年出生までの職業経歴が含まれている。この職業経歴データでは, 戦前の場 合，兵役経験の有無とその期間も尋就らており，出生年と年齢と時代の年次との 関係を基にして, 戦時期における個人の経歴を再構成することができる. 貴重な歴 史資料であるが，これまでの研究においては，戦時期の経歴に注目した分析はほと んど行われていない 1$)$. 本稿は, SSM 調查の 1955 年, 65 年, 75 年デー夕を合併 して， 5 年間隔の出生コーホート別に各年齢における兵役を含めた職業的地位を再 構成し, 戦時期に焦点を当てた分析を試みる ${ }^{2)}$. 分析結果を取り上げる前に, 次節 では研究の背景として, 戦時体制と戦後社会との連続性と非連続性をめぐる議論を 整理しておきたい. 


\section{2 戦時体制と戦後社会——連続性と非連続性}

戦後の日本社会は, 戦前の仕組みから決別することによって達成されたとする理 解に対して, 戦前からの連続性を強調する見解が現在では有力になっている. ジョ ン・ダワーの簡潔な整理によれば, 1931 年の満州事変から 45 年の敗戦に至る「軍 国主義と抑圧の時代」の経済成長や社会政策が，戦後日本の発展に「すこぶる役に 立った」. 戦後の自動車, 造船, 精密機械など製造業の各部門は, 戦時中の発展に 基礎をおくことによって戦後短期間で離陸できた。産業は 15 年間で軍事化の度合 いを深めていたが, 大学工学部や高等工業学校などの拡大によって技術者養成が進 み, 「平時の活動への転換を容易にするようなやり方で, 多様化し高性能化してい た」との評価である（Dower 1993=2010；13），以下では，経歴の流動性に関係す る議論を取り上げておこう。.

\section{1 戦時体制と日本的雇用慣行}

野口悠紀雄による「1940 年体制」論は, 第二次世界大戦後の日本社会の制度的 枠組みが戦時体制によって作られたものであり, その枠組みが戦後の高度経済成長 の原動力になった点を強調する（野口 1995）. 国家総動員体制のもとで, 生活全般 を統制する数々の勅令が制定され，とくに労働と賃金は統制の主要な対象となって いた. 新規学卒者の初任給から勤続年数に応じた昇級までが細かく規定され, 家族 手当や住宅手当も含まれるようになって，職業生活全体が計画化された，とりわけ， 「日本的雇用慣行」の構成要素としてょく知られている, 終身雇用, 年功貨金, 企 業別労働組合を法的に裏書きしたのが戦時体制であったとしている.

戦前の日本社会をみた場合, すでに 1920 年代より都市化と産業化が進み, 大都 市には, いわゆる「サラリーマン」層の生活スタイルが顕在化していた. ホワイト カラー職も増大して, 月給制の職場で働く都市の新中間層が形成されつつあった. 一方ブルーカラー職については, 熟練労働者の「渡り職人」的な転職率の高さが, 企業経営者によって深刻な問題とみなされるようになっていた.

第一次世界大戦直後まで, いわゆる終身雇用制度と年功序列制は確立されておら ず, 好不況の波に応じて, 労働者の採用と解雇が繰り返されていた. しかし 1920 年代より, 大規模な重化学産業の成人男子については, 離職率が低下し, 勤続年数 が急速にのびてきた．当時有能な熟練工を定着させ，労働紛争の高まりにも対処す るため, 企業経営者は「企業内福利施設」を導入し, 「経営家族主義」を鼓舞しな がら、ブルーカラー層に対しても勤続の継続を勧める賃金体系を導入し始めた。そ れと並行するように，年間離職率も 1920 年から 1930 年に大きく低下していた（兵 藤 1971). また同時に企業内昇進や企業内の人材養成も導入されるようになった. 一部の大企業に限定されるのだが，日本的雇用慣行の原型が，すでに 1920 年代よ り姿を現していたとされている（菅山 1989）。ただし日本的雇用慣行の特性は, 主 
としてホワイトカラー職の経歴のモデルであって, ブルーカラー職については, 労 働力不足や労働争議への対応として, 徐々に望ましいとみなされるようになってい た.

アンドリュー・ゴードンの労使関係史によれば（Gordon 1985=2012）, 戦間期か ら戦時期にかけて，1つの企業に定着するような経歴の魅力は増してきたのである が, 1938 年においても, 重工業の主要企業においては, 他社での勤務経験がない 労働者は，入社して間もない者が中心で，全体の半分以下であったと報告されてい る. また戦時下になって「1940 年体制」論が指摘するところの日本的雇用慣行に 関する規制が，政府官僚によって導入が図られたが，具体的に現場にまで浸透した とは言い難い状況であった. ゴードンは, 戦時体制においてもホワイトカラーとブ ルーカラーの待遇の差が大きかった点を強調している．ホワイトカラーとブルーカ ラーを含めた「日本的雇用慣行」は, 戦時期には定着するまでには至らず, 戦後の 労使間の闘争の後, 1950 年代になって定着をみたとしている.

\section{2 高等教育の拡充と技術者の流動性}

戦時期は, 高等教育の規模が大幅に拡大した時期でもあった. 1920 年の高等教 育機関の在学者数(男性) は約 7 万 6,000 人であったが, 30 年に約 16 万 3,000 人 になり，40 年に約 22 万人まで増加していた（文部省 1962；178-9）。しかし 1920 年代後半から 30 年代初めにかけて, 大学・専門学校卒業者の就職率が文系学部で 著しく低下したことはよく知られている. この就職難は, 日中戦争勃発後の好景気 によって解消するのだが, 戦時体制になって理工系を中心に大学の学部定員の拡充 や工業系専門学校の新設が推し進められた（伊藤 1999）。ただし高等教育機関のな かで戦時期に急増したのは工業系・農業系・医療系の専門学校であって, 1940 年 から 45 年の 5 年間で 116 校が新設された。 専門学校が戦時体制の求める「実務的 な専門人材の短期間での効率的な大量養成」を担うべく急増したのであった（天野 2016: 117). 1934 年において高等工業学校・大学卒の勤務先・専攻がわかる技術 者 4 万 1,080 人の中で 2 万 5,331 人が民間部門で働いていた. それが 1942 年には 6 万 1,208 人となり, とくに機械技術者は 5,791 人から 2 万 6,519 人へと約 4.6 倍 の急増であった（沢井 2015：10-16）.

戦時体制のもとで膨大な数の機械技術者が新たに生み出されたのだが，戦後にな って一転して軍需関連産業が閉鎖・縮小されたため, 多くの機械技術者は再就職の 問題に直面した。ただ戦時期から戦後まで軍需関連産業の技術者の移動について, 全体像を数量的に把握することは難しい.

個別の機関や企業に限定されるのだが，沢井実による克明な軍民転換の研究によ れば (沢井 2012), 旧国鉄の鉄道技術研究所は, 陸海軍技術者や航空技術者などに とって，まとまった数の雇用機会を提供してくれる「避難所」であった. 鉄道技術 研究所に勤務した大学卒・高等工業学校卒の研究者数は, 終戦から 1947 年度末に かけて 400 名ほど増加, 48 年度中には 350 名ほど減少, 49 年度にも 100 名近くが 
減少と短期間で増減していた。また 1952 年において鉄道技術研究所の研究室長・ 主任研究員 71 名のなかで 48 名が他所からの転入であった.

沢井は旧帝国大学卒業生の会員名簿『学士会会員氏名録』を用いて, 1943 年に 陸海軍に勤務する帝国大学卒の科学技術者 1,665 名を取り出し, 1950 年代の勤務 先を調べている（沢井 2012）。1,665 名中，1940 年度から 42 年度の 3 年間に卒業 したものが $53.8 \%$ を占めていた. 1951 年に勤務先が確認できた 1,068 名の中で民 間企業に就職は 725 名， 2 名以上雇用する民間企業は 83 社に上る。さらに 1951 年 と 55 年の両年で勤務先がわかる 1,011 名のうち勤務先を変わったものが 213 名, 移動率は $21.1 \%$ となっていた. 1950 年代になって, 大企業に定着する傾向が確認 されているが, 帝大卒といえども一部では経歷が必ずしも安定していたとはいえな い.

\section{3 出生コーホートと経歴の流動性}

戦時下に扔いて，技術開発を担った若手エンジニアが，戦後の製造業の各分野で 技術革新を先導した事例はすでによく知られている（前岡［1993]1996, [2004］ 2013)。ゼ口戦の設計技術者が，優れた技術を転用して戦後の人気軽自動車を生み 出し, 新幹線の開発の担い手となっていた。戦後日本の代表的な技術者の経歴を読 屯限り，1910 年代出生で，1930 年代に工業系の高等教育機関を卒業し，軍需関係 の工場で技術者として働くが，敗戦によって工場が閉鎖され，戦後新たに活躍の場 を見出した例が多い.

たとえば戦後ホンダで 4 輪車の開発と F1 レースへの参戦を主導した中村良夫は 1918 年生まれ, 1942 年に東京帝大航空学科を卒業し中島飛行機に入社, 応召して 陸軍航空技術研究所などで日本初のジェットエンジンの開発に携わるが, 終戦を迎 える. 戦後はオートバイ製作販売を手がけて失敗, オート三輪の有力メーカーで設 計責任者として活躍するが解散となり，1958 年に本田技研に入社している.

軍民転換の研究の中で, 沢井は 4 名の生産管理・工場管理の専門家の経歴と経験 を詳細に検討している（沢井 2013, 2015）。3 名は 1910 年代に生まれており, 戦時 期は陸海軍の技術者もしくは民間の技術者であったが, 戦後に職を転じ, 光学機械 メーカーや家電メーカーの成長を支え, また工場診断の専門家として工場経営の効 率化に多大な貢献をしている. その一人, 高度成長期に三洋電機で家電の量産体制 を確立させた黒河力は 1913 年生まれ, 36 年に旅順工科大学機械工学科を卒業, 陸 軍技術中尉として勤め始め, 42 年に機関銃砲工場長に就任し機関銃の量産システ ムの確立に取り組んでいる。敗戦後 1946 年に故郷の愛媛県松山に㛿り, 蜜柑栽培 に従事する. 50 年に松下金属に入社し， 51 年に三洋電機に転じて，電気製品の量 産に携わる，黒河は機関銃砲工場長時代，多量生産を円滑に進めるために「優秀工 員長又はその候補者」の学術知識の向上と「学歴技術者」の現場体験によって両者 の距離を埋める必要性があると提案をしているが, 戦後に三洋電機で実践されるこ とになる。 
戦時と戦後の断絶があっても, 優れた軍事技術と経験が民間に移転されて戦後の 発展の礎となった，軍事技術の拡散は単純なプロセスではない（中岡編 2002）。技 術者は転職のなかで試行錯誤を重ねながら技術の向上を目指したことになる。また 戦後の民主化措置のもとで, 戦前・戦時にあった職員（ホワイトカラー）と工員 （ブルーカラー）の厳しい区分が崩れつつあったが, 沢井は, 戦時期の生産管理・ 工場管理技術者が戦時期の経験を踏まえ，量産技術や加工技術の向上につながる 「工職一体」の企業組織の形成に貢献した点も強調している（沢井 2013）.

本稿では, 以上の議論を手がかりにしながら, 出生コーホート別に男性の年齢ご との従業先の産業, 従業先移動の回数, 職業上の地位の分布の変化について兵役を 含めて検討する. SSM 調査データではサンプル数の関係から, 高学歴の専門技術 職を取り出して分析することは難しい。デー夕の高学歴層には, 当然医者, 教師, 公務員など多様な職業が含まれる，限界はあるが，本稿は戦時体制の影響が経歴の 変化に顕著にあらわれている出生コーホートを特定し, とくに高学歴層の特徵を読 み取ろうとしている.

\section{3 データの特徵と出生コーホート}

本稿の分析では, SSM 調査のなかで戦時期を経験した調査対象者を多く含む, 1955 年, 65 年, 75 年調查のデー夕を合併させて用いている. まず, 調査対象者の 出生年を 5 年間隔で区分して出生コーホートを構成した. 図 1 によって, 出生コー ホート別に年齢と時代との対応関倸を確認しておこう。図 1 は, 本稿に打いて分析 の対象となる, 1906 年出生コーホートから 1925 年出生コーホートまでの 4 つの出 生コーホートのそれぞれについて，時代の年次と年齢との関倸，ならびに 1955 年， 65 年, 75 年の SSM 調查の調查対象者が属する出生コーホートを示している.

1940 年から 45 年を戦時体制下にあった時期としょう. 図から, 各出生コーホー トが何歳の時に戦時体制に直面したかも読及取れる。たとえば 1906-1910 年出生コ 一ホートの場合, 1940 年が 30-34 歳の年齢に対応し, 1945 年が 35-39 歳に対応す るので, 35 歳の年齢時をみると戦時期の職業的地位がわかるだろう。また 1906-10 年出生コーホートは, 1955 年 SSM 調查では, 調查時点では 45-49 歳の調查対象者 となっており，1965 年 SSM 調査では，55-59歳の調查対象者となっている. 同じ ように各出生コーホートについてみると, 1911-15 年では 30 歳, 1916-20 年出生で は 25 歳, $1921-25$ 年出生では 20 歳と戦時期を経験した年齢は 5 歳ずつ若くなる. 図 1 を基にすると, 戦時体制は, その時期に 20 歳代から 30 歳代を過ごした, 1906-10 年出生から 1921-25 年出生までの 4 つの出生コーホートの経歴に大きな影 響を及ぼしたと予想される。

次に表 1 によって, 出生コーホート別の学歴構成を確認しておこう. 分析では, 旧制高校・高等専門学校卒と旧制大学卒を含めて戦前の高学歴層とする ${ }^{3)}$. 表 1 か ら明らかなように, その数は少ない. 1921-25 年出生でそのコーホート全体の 


\begin{tabular}{|c|c|c|c|c|c|c|c|c|c|c|}
\hline & 1935年 & 1940 年 & 1945年 & 1950 年 & 1955年 & 1960 年 & 1965年 & 1970 年 & 1975年 & ケース数 \\
\hline $\begin{array}{c}\text { 出生コー } \\
\text { ホート }\end{array}$ & 昭和 10 年 & 昭和 15 年 & 昭和 20 年 & 昭和 25 年 & 昭和 30 年 & 昭和 35 年 & 昭和 40 年 & 昭和 45 年 & 昭和 50 年 & $\begin{array}{c}\text { SSM55- } \\
75\end{array}$ \\
\hline $\begin{array}{l}1906-10 \\
\text { 年出生 }\end{array}$ & 25-29歳 & 30-34歳 & 35-39歳 & 40-44歳 & 45-49歳 & 50-54歳 & 55-59歳 & 60-64歳 & 65-69歳 & \multirow[t]{2}{*}{490} \\
\hline $\begin{array}{l}1911-15 \\
\text { 年出生 }\end{array}$ & 20-24歳 & 25-29歳 & 30-34歳 & 35-39歳 & 40-44歳 & 45-49歳 & 50-54歳 & 55-59歳 & 60-64歳 & \\
\hline $\begin{array}{c}1916-20 \\
\text { 年出生 }\end{array}$ & 15-19歳 & 20-24歳 & 25-29歳 & 30-34歳 & 35-39歳 & 40-44歳 & 45-49歳 & 50-54歳 & 55-59歳 & \multirow[t]{3}{*}{588} \\
\hline $\begin{array}{c}1921-25 \\
\text { 年出生 }\end{array}$ & 10-14歳 & 15-19歳 & 20-24歳 & 25-29歳 & 30-34歳 & 35-39歳 & 40-44歲 & 45-49歳 & 50-54歳 & \\
\hline & & \multicolumn{2}{|c|}{ 戦時体制 } & & SSM1955 & & SSM1965 & & SSM1975 & \\
\hline
\end{tabular}

図 1 出生コーホート別にみた年齢と時代 : SSM 調査データ（1955-75 年）の サンプル構成

表 1 出生コーホートと学歴構成（SSM1955-75）

\begin{tabular}{lcccc}
\hline 出生コーホート & $1906-10$ & $1911-15$ & $1916-20$ & $1921-25$ \\
\hline 旧尋常小 & 128 & 89 & 92 & 72 \\
旧高等小 & 253 & 298 & 292 & 379 \\
旧中学·実業·師範 & 65 & 121 & 127 & 151 \\
旧高校·高専 & 28 & 39 & 36 & 66 \\
旧大学 & 11 & 19 & 27 & 31 \\
新中学 & 0 & 2 & 2 & 3 \\
新高校 & 1 & 0 & 1 & 5 \\
新短大·高専 & 0 & 0 & 0 & 0 \\
新大学 & 0 & 1 & 5 & 9 \\
\hline 学歴なし & 3 & 2 & 4 & 0 \\
\hline DK, NA & 1 & 2 & 2 & 1 \\
\hline ケース数 & 490 & 573 & 588 & 717 \\
\hline
\end{tabular}

$13.5 \%$ だが，1940 年の該当年齢人口（18～21 歳）のうち高等教育在学者（男性） の推計值が $6.5 \%$ であるから, サンプルは高学歴層に偏る傾向がある（文部省 1962: 181). ケース数は少なくなるが, 以下の分析結果をみる限り, 高学歴層に限 定しても一定の傾向を読み取ることは可能である.

以上のように再構成した SSM 調査データは, 年齢と時代の対応関係を読み解く ことができるという利点があり, 異なる時代経験を積んだ, 異なる年齢層が折り重 なって形成された戦後の日本社会の特徴を浮き彫りにするために利用価值が高いと いえるだろう。ただし, SSM 調査の職業経歴デー夕は, 戦後の調査時点まで生き 
残った調査対象者によって回顧された情報であるため, 限界も大きい. 戦時期に命 を落とした人々の数や終戦後の平均寿命などを考えれば, それぞれの出生コーホー 卜別に戦前, 戦時, 戦後の実像を再構成できるわけではない. あくまで, 調査時点 まで存命であった調査対象者の回顧的情報に基づく研究結果であることに留意しな ければならないだろう。

職業経歴データには, 調査対象者が経験したすべての職業について, 複数の職業 的地位の情報のみならず, その職業の開始年齢と終了年齢が調べられており, 兵役 に従事した年齢も把握できる。分析では，職業の開始年齢と終了年齢を基にして， 各年齢時における職業的地位を再構成している。 たとえば, 各出生コーホートに対 して, 25 歳時の従業上の地位の分布, 30 歳時の従業上の地位の分布を示し, 年歯令 にともなう分布の変化を検討する. そして, 年齢と時代との対応関係を軸に出生コ 一ホート間の比較によって，経歴に対する時代の影響を読み取ることも可能になる.

本稿の分析では, 出生コーホート別に 20 歳, 25 歳, 30 歳, 35 歳, 40 歳の時点 での従業先の産業, 従業先移動の回数, 職業的地位（兵役を含む）の 3 つの指標の 分布を求め, 出生コーホート全体の特徵と高学歴層に限定した分析結果を提示して いる. そしてさらに, 父職業威信スコア, 本人教育年数, 本人職業威信スコアを用 いた重回帰分析によって, 各年齢における調査対象者の職業的地位が教育年数と父 親の職業によってどの程度説明できるのかを検討している，本稿では，出身階層の 影響について詳しく検討できない. 父職を統制した上での教育水準の職業的地位へ の影響に注目している。

\section{4 戦時期と職業経歴—分析結果}

\section{1 従業先の産業}

まず出生コーホート別に従業先の産業について分析した結果を取り上げよう. 1955 年, 65 年, 75 年 SSM 調査データの産業分類は, 「日本標準産業分類」(1976 年 5 月版）の中分類に基づきコード化されている．分析では，軍需産業に注目する 目的から, 製造業を 2 つのカゴリーに区分している. 鉄鋼, 金属, 機械関係（分 類番号 31-38）を戦時体制下では軍需関係の製造業に関係する産業であると考え, 1 つのカテゴリーにしている. それ以外の製造業のカテゴリーには, 食料, 繊維, 衣服関係の産業（分類番号 18-30）が含まれているが，鉄鋼，金属，機械に注目す る目的から，化学関係は後者のカテゴリーに含めている．以上より，産業の分類は, 農林漁業, 鉱業建築業, 電気運輸, 卸売小売飲食, サービス関係, 製造業（衣食関 係)，製造業（鉄鋼金属機械関係）の７カテゴリーになる，そして「兵役」を加え た 8 カテゴリーについて, 出生コーホート別, 年齢別に各カテゴリーの構成比を検 討している.「その他」には無職や学生, 分類不能が含まれている.

表 2 の 1906-10 年出生の場合をみよう。490 ケースのなかで, 25 歳では $32.9 \%$ が農林漁業， $13.5 \%$ が製造業（衣食関係）， $6.9 \%$ が製造業（鉄鋼機械関係）などと 


\section{表 2 従業先の産業（出生コーホート別, 数值は\%）}

1906-10年出生

\begin{tabular}{|c|c|c|c|c|c|}
\hline & 20 歳 & 25 歳 & 30 歳 & 35 歳 & 40歳 \\
\hline 農林漁業 & 33.1 & 32.9 & 32.2 & 31.8 & 38.8 \\
\hline 鉱業建築業 & 4.7 & 6.7 & 6.7 & 7.1 & 7.1 \\
\hline 電気運輸 & 4.5 & 5.9 & 4.9 & 4.3 & 4.7 \\
\hline 卸売小売飲食 & 13.1 & 13.1 & 12.4 & 10.8 & 12.4 \\
\hline サービス関倸 & 6.3 & 12.7 & 15.7 & 14.5 & 14.1 \\
\hline 製造 (衣食他) & 11.6 & 13.5 & 10.8 & 8.4 & 8.2 \\
\hline 製造 (鉄鋼機械他) & 5.9 & 6.9 & 9.4 & 10.0 & 8.0 \\
\hline 兵役 & 3.3 & 1.2 & 3.1 & 8.4 & 1.8 \\
\hline その他 & 17.6 & 7.1 & 4.7 & 4.7 & 4.9 \\
\hline ケース数 & 490 & 490 & 490 & 490 & 490 \\
\hline \multicolumn{6}{|l|}{ 1916-20年出生 } \\
\hline & 20 歳 & 25 歳 & 30 歳 & 35 歳 & 40 歳 \\
\hline 農林漁業 & 21.4 & 16.3 & 26.7 & 26.4 & 24.9 \\
\hline 鉱業建築業 & 3.4 & 3.6 & 6.5 & 6.5 & 7.6 \\
\hline 電気運輸 & 3.9 & 5.4 & 5.6 & 6.3 & 7.3 \\
\hline 卸売小売飲食 & 10.7 & 5.8 & 12.4 & 13.3 & 13.2 \\
\hline サービス関係 & 9.5 & 12.8 & 18.7 & 20.7 & 21.4 \\
\hline 製造 (衣食他) & 9.5 & 6.5 & 10.7 & 12.8 & 11.1 \\
\hline 製造 (鉄鋼機械他) & 9.7 & 12.8 & 11.1 & 10.4 & 10.8 \\
\hline 兵役 & 12.1 & 27.6 & 3.2 & 0.3 & 0.3 \\
\hline その他 & 19.7 & 9.4 & 5.1 & 3.4 & 3.5 \\
\hline ケース数 & 588 & 588 & 588 & 588 & 370 \\
\hline
\end{tabular}

1911-15年出生

\begin{tabular}{|c|c|c|c|c|c|}
\hline & 20歳 & 25歳 & 30歳 & 35歳 & 40 歳 \\
\hline 農林漁業 & 28.6 & 23.0 & 21.5 & 30.0 & 30.9 \\
\hline 鉱業建築業 & 7.2 & 7.9 & 6.8 & 8.4 & 9.2 \\
\hline 電気運輸 & 4.2 & 5.2 & 5.9 & 6.1 & 5.9 \\
\hline 卸売小売飲食 & 9.8 & 7.2 & 6.1 & 8.9 & 10.5 \\
\hline サービス関係 & 10.3 & 16.2 & 15.0 & 16.6 & 17.6 \\
\hline 製造 (衣食他) & 10.3 & 11.5 & 9.8 & 13.1 & 12.9 \\
\hline 製造 (鉄鋼機械他) & 7.5 & 11.7 & 12.9 & 9.6 & 9.9 \\
\hline 兵役 & 3.5 & 9.1 & 16.9 & 3.0 & 0.3 \\
\hline その他 & 18.7 & 8.2 & 5.1 & 4.4 & 2.6 \\
\hline ケース数 & 573 & 573 & 573 & 573 & 573 \\
\hline \multicolumn{6}{|l|}{ 1921-25年出生 } \\
\hline & 20 歳 & 25 歳 & 30歳 & 35歳 & 40 歳 \\
\hline 農林漁業 & 21.2 & 30.4 & 31.0 & 27.0 & 25.2 \\
\hline 鉱業建築業 & 4.2 & 7.0 & 8.9 & 10.1 & 10.1 \\
\hline 電気運輸 & 5.3 & 8.2 & 8.1 & 5.9 & 6.4 \\
\hline 卸売小売飲食 & 3.8 & 9.8 & 13.1 & 14.7 & 14.0 \\
\hline サービス関係 & 7.9 & 13.5 & 17.0 & 19.1 & 19.5 \\
\hline 製造 (衣食他) & 5.3 & 10.0 & 11.4 & 10.5 & 11.0 \\
\hline 製造 (鉄鋼機械他) & 12.4 & 7.0 & 7.3 & 9.9 & 11.4 \\
\hline 兵役 & 19.5 & 6.6 & 0.8 & 0.2 & 0.2 \\
\hline その他 & 20.4 & 7.5 & 2.2 & 2.6 & 2.2 \\
\hline ケース数 & 717 & 717 & 717 & 456 & 456 \\
\hline
\end{tabular}

（注） 1916-20, 1921-25 年出生コーホートの場合, 調查時点で 35 歳, 40 歳に到達していないケ ースがあるため, サンプル数が減少する. 表 3 , 表 4 も同様.

なっている. 30 歳, 35 歳, 40 歳の時点での数值を辿ることによって, 同じ出生コ ーホート内での年齢に伴う分布の変化をみることができる。この出生コーホートの 35 歳が 1940 年代前半に対応する. 35 歳の時点では, 製造業（鉄鋼機械関係）が $10.0 \%$ に増え，40 歳になると $8.0 \%$ に低下している．兵役をみると， 30 歳の $3.1 \%$ が 35 歳には $8.4 \%$ となっており, 戦時期になって戦争に動員されたことが読み取 れる.この出生コーホートの 40 歳は, 終戦直後の時期に対応する. 兵役は $1.8 \%$ になるが，農林漁業は 35 歳時の $31.8 \%$ が 40 歳時には $38.8 \%$ に昇している.す なわち，戦時期には製造業（鉄鋼機械関係）と兵役の比率が高まり，終戦直後には 製造業（鉄鋼機械関係）が低下し，農林漁業が高まったことになる，つまり，敗戦 後に農林漁業への移動があったことがわかる.

1911-15 年出生になると，25 歳で衣食関係の製造業と鉄鋼機械関係の製造業の割 
合がほぼ等しく, 30 歳になると鉄鋼機械関倸の製造業の割合が衣食関倸の製造業 の割合を上回っている. また 30 歳の兵役割合は $16.9 \%$ と高い。その後, 35 歳と 40 歳では鉄鋼機械関係がやや低下し，衣食関倸の製造業がやや上昇している。 た 35 歳と 40 歳では農林漁業の割合と卸売小売飲食も上昇している. 1911-15 年出 生の 30 歳が 1940 年代に前半に対応するので, 1906-10 年出生よりも若い年齢時に 戦時期の影響があらわれている.

1916-20 年出生の場合, 25 歳が 1940 年代前半になる. 25 歳の鉄鋼機械関係の製 造業が $12.8 \%$ と高くなり, 兵役も 25 歳で $27.6 \%$ となっている. 30 歳以後になる と, 農林漁業, 卸売小売飲食, サービス関係の割合が高まっている. また衣食関係 の製造業がやや高まり，鉄鋼機械関係はやや低下している.

1921-25 年出生では, 20 歳が 1940 年代前半に当たる. 20 歳において兵役が 19.5\%あり，鉄鋼機械関係の製造業が $12.4 \%$ である. 25 歳は終戦後になるが, 鉄 鋼機械関係の製造業の割合は低下し，衣食関係の製造業がやや高まっている. 25 歳以後は農林漁業やサービス関係, 卸売小売飲食の高まる傾向がある.

表 3 は, 高学歴層に限定して同様の分析を行った結果である. 1906-10 年出生の 場合， 25 歳では衣食関係の製造業は $15.4 \%$ でるが， 30 歳では $5.1 \%, 35$ 歳では $2.6 \%$ に低下する。一方鉄鋼機械関係の製造業は, 25 歳時に $7.7 \%$ だが, 30 歳で $15.4 \%, 35$ 歳で $17.9 \%$ になってる. また 35 歳時の兵役も $15.4 \%$ となっていて, ケース数は少ないのだが, 戦時体制の影響を読み取ることができる. 1911-15 年出 生では, 30 歳時の鉄鋼機械関係の製造業と兵役の割合に, 同様の特徵があらわれ ている. そして 35 歳時に兵役がほぼくなり鉄鋼機械関係の製造業がやや低下し, その一方, 衣食関係の製造業とサービス関係がやや上昇することから, 敗戦後の職 業移動を読み取ることができる。

1916-20 年出生に注目したい。戦時期の 25 歳では兵役が $20.6 \%$, 鉄鋼機械関倸 の製造業が $14.7 \%$ ある. 敗戦後の 30 歳をみると, サービス関係, 鉄鋼機械関係 の製造業, 衣食関倸の製造業の割合が高くなっていて, とくに鉄鋼機械関倸の製造 業は $20.6 \%$ となっていて, 25 歳時よりも高まっている. 1916-20 年出生の高学歴 層は, 戦後も鉄鋼機械関係と衣食関係の製造業で仕事を得たことになる. しかし敗 戦後に職業を開始した 1921-25 年出生では, サービス関係の割合が高く, 製造業の 割合は高くない.

以上のように, 出生コーホート別に就業先の産業の分布について, 兵役を含めて 年齢にともなう変化を検討すると, 戦時期の経歴の流動化が比較的よく理解できる. 1906-10 年出生から 1921-25 年出生の 4 つの出生コーホートのそれぞれにおいて, 戦時体制と経歴との対応関係がはっきりとあらわれている．出生コーホート全体を みると，戦時期には鉄鋼機械関係の製造業の割合が高まり，衣食関係の製造業の割 合が低下していた。鉄鋼機械関係の製造業が軍需産業に関係すると考えれば，大量 動員の影響を読み取ることができる.また兵役経験の増減も時代に対応していた． 敗戦後には, 鉄鋼機械関係の製造業が低下し, 農林漁業とサービス関倸の第三次産 
表 3 高学歴層における従業先の産業（出生コーホート別, 数値は\%）

1906-10年出生

\begin{tabular}{|c|c|c|c|c|}
\hline & 25 歳 & 30 歳 & 35 歳 & 40歳 \\
\hline 農林漁業 & 2.6 & 2.6 & 2.6 & 10.3 \\
\hline 鉱業建築業 & 2.6 & 7.7 & 7.7 & 7.7 \\
\hline 電気運輸 & 2.6 & 5.1 & 7.7 & 2.6 \\
\hline 卸売小売飲食 & 7.7 & 7.7 & 7.7 & 10.3 \\
\hline サービス関係 & 46.2 & 43.6 & 35.9 & 35.9 \\
\hline 製造 (衣食他) & 15.4 & 5.1 & 2.6 & 7.7 \\
\hline 製造 (鉄鋼機械他) & 7.7 & 15.4 & 17.9 & 12.8 \\
\hline 兵役 & 2.6 & 7.7 & 15.4 & 7.7 \\
\hline その他 & 12.8 & 5.1 & 2.6 & 5.1 \\
\hline ケース数 & 39 & 39 & 39 & 39 \\
\hline \multicolumn{5}{|l|}{ 1916-20年出生 } \\
\hline & 25 歳 & 30 歳 & 35 歳 & 40 歳 \\
\hline 農林漁業 & 0.0 & 5.9 & 2.9 & 4.7 \\
\hline 鉱業建築業 & 2.9 & 2.9 & 2.9 & 2.3 \\
\hline 電気運輸 & 4.4 & 1.5 & 4.4 & 4.7 \\
\hline 卸売小売飲食 & 2.9 & 8.8 & 8.8 & 9.3 \\
\hline サービス関係 & 23.5 & 36.8 & 39.7 & 34.9 \\
\hline 製造 (衣食他) & 8.8 & 10.3 & 14.7 & 14.0 \\
\hline 製造 (鉄鋼機械他) & 14.7 & 20.6 & 20.6 & 23.3 \\
\hline 兵役 & 20.6 & 4.4 & 0.0 & 0.0 \\
\hline その他 & 22.1 & 8.8 & 5.9 & 7.0 \\
\hline ケース数 & 68 & 68 & 68 & 43 \\
\hline
\end{tabular}

1911-15年出生

\begin{tabular}{lrrrr}
\hline & 25 歳 & 30 歳 & 35 歳 & 40 歳 \\
\hline 農林漁業 & 0.0 & 0.0 & 3.4 & 5.2 \\
鉱業建築業 & 3.4 & 1.7 & 1.7 & 1.7 \\
電気運輸 & 5.2 & 5.0 & 3.4 & 3.4 \\
卸売小売飲食 & 3.4 & 1.7 & 3.4 & 8.6 \\
サービス関倸 & 50.0 & 46.6 & 53.4 & 51.7 \\
製造 (衣食他) & 6.9 & 8.6 & 13.8 & 15.5 \\
製造 (鉄鋼機械他) & 8.6 & 17.2 & 15.5 & 13.8 \\
兵役 & 3.4 & 13.8 & 1.7 & 0.0 \\
その他 & 19.0 & 5.2 & 3.4 & 0.0 \\
\hline ケース数 & 58 & 58 & 58 & 58 \\
\hline
\end{tabular}

1921-25年出生

\begin{tabular}{lrrrr}
\hline & 25 歳 & 30 歳 & 35 歳 & 40 歳 \\
\hline 農林漁業 & 6.6 & 7.5 & 7.0 & 8.5 \\
鉱業建築業 & 6.6 & 9.4 & 9.9 & 9.9 \\
電気運輸 & 6.6 & 4.7 & 2.8 & 2.8 \\
卸売小売飲食 & 12.3 & 15.1 & 12.7 & 14.1 \\
サービス関係 & 33.0 & 44.3 & 47.9 & 45.1 \\
製造 (衣食他) & 12.3 & 11.3 & 9.9 & 9.9 \\
製造 (鉄鋼機械他) & 7.5 & 4.7 & 8.5 & 7.0 \\
兵役 & 0.9 & 0.9 & 0.0 & 0.0 \\
その他 & 14.2 & 1.9 & 1.4 & 2.8 \\
\hline ケース数 & 106 & 106 & 71 & 71 \\
\hline
\end{tabular}

業が労働力を吸収したことも明らかである.

しかし高学歴層に限定して分析すると, やや異なる傾向がみられる. 戦時期に兵 役や軍需産業に動員された 1916-20 年出生では, 戦後も製造業の割合が維持されて いる.この結果には, 戦時体制下の 20 歳代に軍隊や軍需産業に従事した高学歴層 が, 戦後も製造業で仕事を続け, 復興の担い手となった点が反映していると読み取 れる。

\section{2 従業先移動}

従業先移動の分析結果に移ろう. SSM 調査は, それぞれの職業について働き始 めてからの経歴のなかで何番目の従業先で働いたかに関する情報も収集している. 本稿の分析では，従業先の産業の分析と同様に，出生コーホート別に 5 つの年齢時 を取り上げ，仕事に従事している場合には，最初の従業先であるか， 2 番目の従業 先であるか, 3 番目以降の従業先であるかを分類した. そして各年齢における従業 
表 4 高学歴層の従業先移動（出生コーホート別, 数値は\%）

1906-10 年出生

\begin{tabular}{lrrrr}
\hline & 25 歳 & 30 歳 & 35 歳 & 40 歳 \\
\hline 従業先 1 & 66.7 & 56.4 & 38.5 & 15.4 \\
従業先 2 & 15.4 & 15.4 & 17.9 & 33.3 \\
従業先 3 & 2.6 & 15.4 & 25.6 & 38.5 \\
\hline 兵役 & 2.6 & 7.7 & 15.4 & 7.7 \\
その他 & 12.8 & 5.1 & 2.6 & 5.1 \\
\hline ケース数 & 39 & 39 & 39 & 39 \\
\hline 1916-20 年出生 & & & & \\
\hline & 25 歳 & 30 歳 & 35 歳 & 40 歳 \\
\hline 従業先 1 & 44.1 & 32.4 & 29.4 & 30.2 \\
従業先 2 & 11.8 & 35.3 & 29.4 & 30.2 \\
\hline 従業先 3 & 1.5 & 19.1 & 35.3 & 32.6 \\
兵役 & 20.6 & 4.4 & 0.0 & 0.0 \\
その他 & 22.1 & 8.8 & 5.9 & 7.0 \\
\hline ケース数 & 68 & 68 & 68 & 43 \\
\hline
\end{tabular}

$1911-15$ 年出生

\begin{tabular}{lrrrrr}
\hline & 25 歳 & 30 歳 & 35 歳 & 40 歳 \\
\hline 従業先 1 & 65.5 & 51.7 & 34.5 & 31.1 \\
従業先 2 & 8.6 & 20.7 & 29.3 & 31.1 \\
従業先 3 & 3.4 & 8.6 & 31.0 & 37.9 \\
兵役 & 3.4 & 13.8 & 1.7 & 0.0 \\
その他 & 19.0 & 5.2 & 3.4 & 0.0 \\
\hline ケース数 & 58 & 58 & 58 & 58 \\
\hline 1921-25 年出生 & & & & \\
\hline & 25 歳 & 30 歳 & 35 歳 & 40 歳 \\
\hline 従業先 1 & 51.9 & 41.5 & 43.7 & 40.8 \\
従業先 2 & 24.5 & 34.9 & 32.4 & 29.6 \\
徉業先 3 & 8.5 & 20.8 & 22.5 & 28.2 \\
兵役 & 0.9 & 0.9 & 0.0 & 0.0 \\
その他 & 14.2 & 1.9 & 1.4 & 1.4 \\
\hline ケース数 & 106 & 106 & 71 & 71 \\
\hline
\end{tabular}

先番号それぞれの割合を求めて, 出生コーホート間で比較を行っている。「従業先 1」とは，最初の従業先で働いているものの割合であり，転職経験なしを意味する. 「従業先 $2 」$ とは, 2 番目の従業先で働いているもの, すなわち転職経験 1 回を意味 する.「従業先 $3 」$ は, 3 番目以降の従業先で働いているもの, すなわち転職経験 2 回以上を含んでいる.

表 4 は, 高学歴層に限定して従業先移動に関する分析を行った結果である. 1906-10 年出生では, 戦時期の 35 歳時で $25.6 \%$ が 2 回以上従業先移動を経験して おり，敗戦後の 40 歳時には $38.5 \%$ となっている. 1911-15 年出生についても， 35 歳時で $29.3 \%$ が 1 回転職, $31.0 \%$ が 2 回以上転職を経験している. 1916-20 年出生 を見ると, 敗戦後の 30 歳時で $35.3 \%$ が 1 回転職, $19.1 \%$ が 2 回以上の転職を経験 しているが, 35 歳で 2 回以上転職がさらに増え $35.3 \%$ にっている. 戦後の 1940 年後半から 50 年代にかけて, この出生コーホートの高学歴層は従業先を移動する 割合が高かったといえる.

1921-25 年出生になると, 転職なしの割合が高まり, 2 回以上の従業先移動をし ている割合も，前の出生コーホートに比べると低くなっている．比較のために, 1926-30 年出生, 1931-35 年出生, 1936-40 年出生の高学歴層についても触れてお くと, 若い出生コーホートほど転職経験が少なく, 転職なしの割合が高い. 年齢に ともない転職割合も高まるが, 1931-35 年出生と 1936-40 年出生になって, 最初の 従業先で就業を継続する傾向が顕著になっている．高学歴層が最初の従業先に定着 
し, 経歴の流動性が低いという特徵は, 1950 年代半ば以降に職業経歴を開始した 出生コーホートから当てはまる.

従業先移動の回数を経歴の流動化を示す指標とするならば, 本項の分析結果が明 らかにしたように, 戦時期から戦後にかけて兵役や軍需産業への動員によって高学 歴層の経歴も流動性が高かった. 高学歴層が最初の従業先に定着する傾向は, 戦後 の 1950 年代になってからの現象である.

\section{3 職業的地位}

SSM 調査の分析では, 職業の内容を示す標準的な指標として, 専門職, 管理職, 事務職, 販売職, 熟練職, 半熟練職, 非熟練職, 農業の SSM 職業 8 分類が用いら れてきた，その際，職業経歴のなかで職業に従事していない場合には，兵役や学生， 無職の分類も可能ともなっている. 本稿では, サンプル数の関係から SSM 職業 8 分類のなかで熟練職, 半熟練職, 非熟練職を「マニュアル職」として統合して 5 カ テゴリーとし, 農業と兵役を加えた 7 カテゴリーの職業的地位の指標を再構成し, 出生コーホート別の経歴の推移を分析した。 その分析結果には表 2 と同様, 戦時期 に当たる年齢において兵役経験が増加し, 戦後になると農業が増加するという傾向 が顕著にあらわれていた。

高学歴層の分析結果を紹介しておこう (表は略)。1906-10 年出生の場合, 専門・ 管理・事務職が多いのだが, 25 歳と 30 歳でマニュアル職もあり, 敗戦後の 40 歳 時では農業も増えている. 1911-15 年出生では, 戦時期の 30 歳時では, 専門 $32.8 \%$, 管理 $1.7 \%$, 兵役 $13.8 \%$ であたが, 戦後の 35 歳時になると兵役が $1.7 \%$, 専門 $39.7 \%$, 管理 $15.5 \%$ になる. 1916-20 年出生をみると, 戦時期の 25 歳時で専門 $22.1 \%$, 管理 $1.5 \%$, 兵役 $20.6 \%$ であるが, 30 歳時に専門 $30.9 \%$, 管 理 $13.2 \%$, 兵役 $4.4 \%$ と分布が変化する. 1921-25 年出生の場合, 専門は 25 歳で $25.5 \%, 30$ 歳で $34.0 \%$ となっている.

従業先移動の分析結果によれば, 1911-15 年出生ならびに 1916-20 年出生は戦時 期から敗戦後にかけて従業先移動が増大していた. 高学歴層の場合, 従業先移動の 結果として, 戦後の職業的地位が専門と管理に集中するようになった.つまり, 高 学歴と職業的地位との結びつきが強化されたといえる.

\section{4 職業的地位達成に及ぼす教育と父職の影響}

最後に, 出生コーホート別に各年齢時における本人の職業威信を従属変数とし, 教育年数と父職業威信を独立変数とした重回帰分析の結果を検討しておこう ${ }^{4)}$. 表 5 は, 出生コーホート別年齢別に行った重回帰分析の結果として独立変数の標準化 回帰係数とモデルの決定係数(調整済み) の值を示している.

1906-10 年出生の分析結果をみよう。職業威信に対する教育年数の影響は, どの 年齢でも統計的に有意であるが，影響力は年齢とともにやや低下している．父職業 威信の影響は 35 歳まで有意ではなく, 敗戦後の 40 歳になって有意傾向となってい 
表 5 職業的地位に対する教育と父職の影響（重回帰分析の結果） 1906-10年出生

\begin{tabular}{|c|c|c|c|c|}
\hline 独立変数 & 25 歳 & 30 歳 & 35 歳 & 40 歳 \\
\hline 教育年数 & $0.487 * * *$ & $0.482^{* * *}$ & $0.460^{* * *}$ & $0.433 * * *$ \\
\hline 父職業威信 & $0.056^{\mathrm{ns}}$ & $0.044^{\mathrm{ns}}$ & $0.042^{\mathrm{ns}}$ & $0.098^{+}$ \\
\hline 決定係数 & 0.254 & 0.243 & 0.244 & 0.216 \\
\hline \multicolumn{5}{|c|}{ 1911-15年出生 } \\
\hline 独立変数 & 25 歳 & 30 歳 & 35 歳 & 40 歳 \\
\hline 教育年数 & $0.511^{* * *}$ & $0.463^{* * *}$ & $0.489^{* * *}$ & $0.463 * * *$ \\
\hline 父職業威信 & $0.146^{* * *}$ & $0.094 *$ & $0.128^{* *}$ & $0.150 * *$ \\
\hline 決定係数 & 0.303 & 0.258 & 0.304 & 0.292 \\
\hline \multicolumn{5}{|c|}{ 1916-20年出生 } \\
\hline 独立変数 & 25 歳 & 30 歳 & 35 歳 & 40 歳 \\
\hline 教育年数 & $0.548^{* * *}$ & $0.492^{* * *}$ & $0.467^{* * *}$ & $0.504^{* * *}$ \\
\hline 父職業威信 & $0.097^{*}$ & $0.143^{*}$ & $0.210^{* * *}$ & $0.189^{* * *}$ \\
\hline 決定係数 & 0.350 & 0.325 & 0.350 & 0.377 \\
\hline \multicolumn{5}{|c|}{ 1921-25年出生 } \\
\hline 独立変数 & 25 歳 & 30 歳 & 35 歳 & 40 歳 \\
\hline 教育年数 & $0.443^{* * *}$ & $0.473^{* * *}$ & $0.466^{* * *}$ & $0.430 * * *$ \\
\hline 父職業威信 & $0.219^{* * *}$ & $0.187^{* * *}$ & $0.203^{* * *}$ & $0.192^{* * *}$ \\
\hline 決定係数 & 0.315 & 0.328 & 0.332 & 0.279 \\
\hline
\end{tabular}

る. 決定係数については, 年齢とともにやや説明力が低下している.

1911-15 年出生についても, 教育年数の影響力はどの年齢においても強い. しか し父職業威信については, 戦時以前の 25 歳時点で影響力がやや強く有意だが, 戦 時期の 30 歳時点になると影響力がやや低下する. そして敗戦後の 35 歳と 40 歳で は, 影響力がやや強くなっている. 決定係数も 35 歳時点でやや高い.

1916-20 年出生では 30 歳時点で敗戦後となる. 教育年数の影響力は 25 歳から 40 歳までかなり高いが, 父職業威信の影響力は, 戦時の 25 歳ではやや弱く, 敗戦後 の 30 歳と 35 歳になって強くなっている. 決定係数も各年齢で高い值となっており, 表 5 の分析結果のなかでは最も高い. 1921-25 年出生においても, 敗戦後の 25 歳 と 30 歳の時点で教育年数とともに父職業威信の影響力が有意となっており, 決定 係数も比較的高い值になっている.

以上のように，年齢と時代とを対応させて，それぞれの年齢における本人の職業 威信を従属変数とし, 教育年数と父職業威信を独立変数にした重回帰分析を行うと, 
本人の職業威信に対する父職業威信の影響力は, 戦時期にやや弱く, 戦後社会への 移行の時期に強くなっている. 戦時期から戦後にかけて, 高学歴層だけではなく他 の学歴層でも従業先を移動する傾向が強かったが, そのプロセスで出身階層の影響 力が強まったことになる。.また表 5 の結果が示すように, 戦時期から敗戦後にかけ ての従業先移動の結果, 高学歴層の職業的地位が強化されていた. 戦時経済は, 経 歴の流動化を進めたが, 敗戦とともに, 軍需産業からの移動や兵役からの復員によ って, 従業先移動がさらに高まる段階になって, 出身階層の影響力が高まったとし ても, 職業的地位に対する本人の教育水準の影響力は一貫して高い.

\section{5 戦後社会への「遺産」一一高学歴層の流動性と戦後階層システム}

戦時体制下において，男性従業員の職場への定着を図るべく，いわゆる「日本的 雇用慣行」の構成要素である終身雇用，年功賃金，企業別組合などに関する法的な 整備が進められた，その一方，戦時期は軍需産業への動員や兵役などによって，日 本人男性の経歴の流動性が例外的に高かった. 一般に日本の高学歴層は, 学校卒業 後に就職した職場で安定的な経歴を歩むと考えられている. しかし本稿の分析結果 が示すように, 戦時期から戦後にかけて高学歴層の経歴も流動性が高かった. この 流動性の高さは戦後の日本社会にとってどのような意味をもったのであろうか.

分析結果のなかで, 1916-20 年出生の高学歴層の経歴が特徵的であった.この出 生コーホートが高等教育に進学するのは, 戦時体制下で高等教育が大幅に拡大して いた時期であった．卒業後は軍需関係の産業に就業するか兵役によって戦場に送ら れたが, 敗戦後は転職も多く, 良好な職業的地位を得ていた。製造業で仕事を継続 する傾向も強かった．1911-15 年出生の経歴も類似していた. 1910 年代出生の高学 歴層は, 戦争によって大きな痛手を負ったことは間違いないが, 戦後日本社会の復 興の担い手となり, 戦後の階層システムの上層を形成したといえるだろう. 軍需産 業から民間企業に移動して活躍した高学歴技術者層もここに含まれる. 現在の時点 からみれば, 戦時体制から戦後まで, 高学歴層の経歴が流動的であったために, 戦 後になって高学歴と職業との関係が強化されたと考えられる.

戦時体制のもとで, 大規模な軍需工場や軍隊は社会的背景の異なる人々が大量に 動員された結果，平時の日常生活では出会うことのない人間が接触し合う場ともな っていた (小池 1976; 猪木 2016). 中小企業で働いていた人々が, 旧制高校から旧 帝国大学を辿ったエリート層と日常的に触れ合う例外的な機会であった. $2.3 て ゙$ で り上げた黒河力の提案もこのような経験から生まれている. 高学歴層の流動性は, 戦後社会でエリート層とそれ以外との障壁を崩すことに貢献したと考えられる5).

ジェームス・アベグレンの『日本の経営』（Abegglen 1958=1958）では, 195556 年の調査に基づき, 高学歴層の経歴の安定性と非流動性が強調され, 1920 年代 に登場した「原型」との連続性が論じられていた。 そこでは, 戦時期から戦後にか けての高学歴層の流動性が見落とされていた. 
$\lceil 1940$ 年体制」について, ゴードンは戦前・戦時・戦後にまたがって続く, 一連 の「貫戦的な（transwar）」な政策上の方針とみなした方がよいと指摘する（Gordon $2013=2013)$ ． 戦後社会に定着した諸政策のルーツは，昭和恐慌期から敗戦ま でにわたる時期に行われた試行錯誤にあった。その試行錯誤を経て, 政策上の認識 枠組みが作られたのだが, 戦時下の状況では実現が困難であった。 むしろ認識枠組 みとして戦後まで存続し, 戦後社会の変化を方向付けた。同様に 1940 年代につい ても, ゴードンは戦前から戦後へと戦時期を貫いて途切れなくつづく「貫戦的なひ とつの社会」とみることが可能だと指摘する。本稿は, SSM 調査の職業経歴デー 夕を分析することによって, 戦前から戦時を経て戦後へと続く「貫戦的な」人生パ ターンの諸相を描いた。 その中で, 高学歴層の流動性が, とりわけ戦前の高等教育 と戦後の階層システムの安定性をつなぐ役割を果たしたことになる.

[付記］「社会階層と社会移動（SSM）」調查デー夕の利用に関しては, 2005 年 SSM 調查委員会 の許可を得ている。 また本研究の一部は, 2013 年度 (平成 25 年度)「日本経済研究センター研究奨 励金」の援助を受けている.

\section{[注]}

1）職業経歴データを歴史資料として計量分析した研究として, 渡邊勉 (2015), 橋本健二 （2016）がある.

2) 岩井 $(2014,2015)$ は 1955 年調查と 65 年調查を合併させたデー夕に基づく分析である。本 稿では, 75 年調查デー夕も合併している。

3）分析では, 戦前の制度から戦後への移行を考慮し, 1915-20 年出生と 1921-25 年出生の新制 大学卒の 5 ケース, 9 ケースも高学歴層に含めている。1911-15 年出生の 1 ケースは含めてい ない.

4）教育年数は, 旧尋常小 $=6$ 年, 旧高等小 $=8$ 年, 旧中学 • 実業学校・師範学校 $=11$ 年, 旧高 校・高専 $=14$ 年, 新大学 $=16$ 年, 旧大学 $=17$ 年として分析で用いている.

5）小池は, 社会的背景の異なる人間が接触し合うことによって, 自己を向上させようとする強 い動機が生まれることを「接触効果」と呼び，この戦時体制下において生じた「接触効果」が， 戦後社会の進学競争の基礎となり, 戦後の経済活動の基盤を形成したと論じている（小池 1976).

\section{[文献]}

Abegglen, James C., 1958, The Japanese Factory: Aspects of its Social Organization, Glencoe: Free Press. (=1958, 占部都美監訳『日本の経営』ダイヤモンド社.)

天野郁夫, 2016, 『新制大学の誕生一一大衆高等教育への道』上・下, 名古屋大学出版会.

Dower, John W., 1993, Japan in War \& Peace: Selected Essays, New York: The New Press. (=2010, 明田川融訳『昭和一一戦争と平和の日本』みすず書房. )

Gordon, Andrew, 1985, The Evolution of Labor Relations in Japan: Heavy Industry, 1983-1955, Cambridge: Harvard University Council on East Asian Studies Monographs. (=2012, 二村一 夫訳『日本労使関係史——1853-2010』岩波書店.)

—, 2013, A Modern History of Japan: From Tokugawa to the Present, Third Edition, New 
York: Oxford University Press. (=2013, 森谷文昭訳『日本の 200 年一一徳川時代から現代ま で (新版)』上・下，みすず書房. )

橋本健二，2016，『はじまりの戦後日本一一激変期をさまよう人々』河出書房新社.

兵藤釗，1971，『日本における労資関係の展開』東京大学出版会.

猪木武徳, 2016, 『増補 学校と工場—二十云世紀日本の人的資源』筑摩書房.

伊藤彰浩, 1999, 『戦間期日本の高等教育』玉川大学出版部.

岩井八郎, 2014, 「戦時経済の『遺産』仮説の検討—SSM 調查の再分析」『京都大学大学院教育学

研究科紀要』60:25-43.

——, 2015, 「戦時体制による経歴の流動化と戦後社会—SSM 調查の再分析」橋本健二編

『戦後日本社会の誕生』第 6 章, 弘文堂, 209-47.

小池和男, 1976, 「戦時経済の『遺産』」飯田経夫 · 清成忠男 - 小池和男 - 玉城哲 - 中村秀一郎 - 正

村公宏・山本満著『現代日本経済史一一戦後三○年の歩み』上，筑摩書房， 92-107.

前岡孝則, [1993]1996, 『マン・マシンの昭和伝説——航空機から自動車へ』上・下, 講談社.

一, [2004]2013, 『技術者たちの敗戦』草思社.

文部省, 1962, 『日本の成長と教育——教育の展開と経済の発展』.

中岡哲郎編, 2002, 『戦後日本の技術形成一模倣か想像か』日本経済評論社.

中村隆英, [1993]2012, 『昭和史』上・下, 東洋経済新社.

野口悠紀雄, 1995, 『1940 年体制—さらば「戦時経済」』東洋経済新社.

沢井実, 2012, 『近代日本の研究開発体制』名古屋大学出版会.

——, 2013, 「生産管理・工場管理専門家の軍民転換」『大阪大学経済学』63(2): 1-14.

——，2015，『帝国日本の技術者たち』(歴史文化ライブラリー 399) 吉川弘文館.

菅山真次, 1989,「戦間期雇用関係の労職比較——終身雇用』の実態」『社会経済史学』55(4):

$1-33$.

渡邊勉, 2015, 「徵兵と職業経歴—SSM 調查データによる徵兵と職業経歴の関連」『関西学院大学

社会学部紀要』121: 45-65. 


\title{
Wartime Mobilization of Highly Educated Men and its Impact on the Postwar Stratification System:

\author{
Rethinking the 1940s Based on SSM Work History Data
}

\author{
IWAI, Hachiro \\ Kyoto University
}

Iwai.hachiro.2r@kyoto-u.ac.jp

\begin{abstract}
During World War II, a large number of Japanese men were drafted in military service or forced to work for military factories. How could this massive wartime mobilization contribute to forming a stable postwar Japanese society? This paper explores the influences of wartime mobilization on career mobility of Japanese men, using 1955, 1965, and 1975 Social Stratification and Mobility surveys. This paper first attempts to reconstruct life history data of respondents that enable us to analyze the relations between wartime experiences and careers. The analyses of the life history data then revealed that there were clear age differences in wartime experiences among birth cohorts. Highly educated men of the 1916-20 birth cohort tended to be forced to work for military factories or drafted. After the war, they tended to switch workplaces more often and achieve better occupational status. In addition, multivariate analyses of occupational attainment indicated that educational levels and fathers' occupations strongly influenced patterns of occupational transitions from wartime to the postwar period among people who experienced wartime mobilization in their twenties or thirties. Using these results of analyses, this paper argues that the fluidity of highly educated men from wartime to the postwar period contributed to forming a stable postwar stratification system.
\end{abstract}

Key words: wartime mobilization, career fluidity, highly educated strata 